Urszula Drozdowska

\title{
PATIENTS' RIGHTS PROTECTION MODEL IN THE PATIENTS' RIGHTS AND PATIENTS' RIGHTS OMBUDSMAN ACT OF 6.11.2008
}

\section{Introductory remarks}

On the 21 May 2009, the abovementioned Patients' Rights and Patients' Rights Ombudsman Act ${ }^{1}$ entered into force. The act was passed due to the need of having a comprehensive regulation on patients' rights and the legal instruments for their protection.

This, however, does not mean that the Polish legal system in this field has not been regulated before. In the Health Care Institutions Act of 30.08.1991'2 there was, admittedly, a catalogue of patients' rights, but it concerned only some rights. Moreover, the act did not specify the substance of individual rights, which was the reason why for this purpose, one has to refer to other acts in the fields of medical law, such as: the Doctor and Dentist Professions Act of 5.07.1996 ${ }^{3}$, the Nurse and Midwife Professions Act of 5.12.2008 ${ }^{4}$, Act on Infectious Diseases and Infections of 19.09.1994', and Mental Health Act of 19.09.1994' ${ }^{6}$. The abovementioned legal acts define either the rights of particular patients' groups - like e.g. the Mental Health Act - which regulates the rights of the mentally ill, or, like the Act on Infectious Diseases and Infections - the rights of the ill with infectious diseases. If compared to the regulations of the Patients' Rights Act, these acts are of a specific character which complements a given field of interest. On the other hand, the corporate acts concerning the rights to practice medical professions, primarily focus on defining

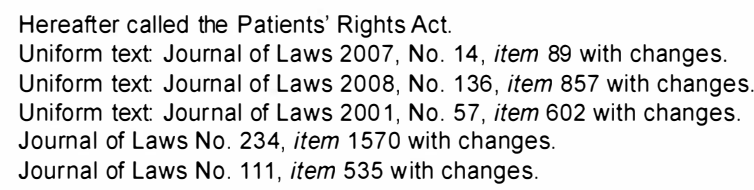


the obligations of medical personnel towards patients 7 . Therefore, it is necessary to properly explain the patients' rights, as well as to introduce certain changes - first of all those which would give additional entitlements to the patients.

The aim of the legislator was to introduce a new means for the protection of patients' rights - namely the institution of the Patients' Rights Ombudsman (PRO) serving as an organ representing interests of all patients, which is independent of the National Health Fund and other entities providing health care services. It should be pointed out that in the former legal system, this function was managed by the following organs: Patients' Rights Office functioning under the Ministry of Health, patients' rights ombudsmen appointed in mental hospitals and patients' rights ombudsmen working under the National Health Fund ${ }^{8}$.

Dispersion of these organs, their location in the structure of the entities providing health care services (as in the case of ombudsmen appointed in mental psychiatric hospitals) or connection with the tasks being performed in order to finance health care services (as in the case of the National Health Fund's employees), as well as lack of adequate competences of the abovementioned organs, were the reasons the separate institution of the Patients' Rights Ombudsman was created.

According to the introductory provisions of the Patients' Rights Act ${ }^{9}$, the abovementioned Patients' Rights Office under the Minister of Health became the office of PRO. This solution was found to be beneficial as it saved the cost of creating a new PRO office, moreover, it took advantage of using the experience of people who had already dealt with patients' rights issues.

This publication's aim is to acquaint its readers with the current model of the Polish, legally binding, patients' rights protection system. The leitmotiv of the publication is the indication of new legal categories. Firstly, axiological assumptions on patients' rights protection are shown as well as basic definitions which occur in the area of study. Secondly, I will deal with the legally binding catalogue of patients' rights and the legal instruments for their protection in Poland which were created on the basis of the Patients' Right Act.

Obligations of the medical staff are correlate of the patients' rights and, as a result, undoubtedly, specify the substance of these rights. Nonetheless, making these issues understandable requires the introduction of adequate changes.

8 It may be assumed that this kind of tasks are performed by the Civil Rights Ombudsman and, with respect to under age patients - the PRO. This assumption is legitimate since patients' rights are part of the broadly defined human rights.

Act of 24 April 2009., Journal of Laws No. 76, item 641. 


\section{Axiological conditionings of patients' rights}

Patients' rights constitute a particular category of human rights. This is why the literature defines it as human rights applying to a specific institution (primarily healthcare institutions) or to representatives of medical professions who perform certain professional or official duties ${ }^{10}$.

Why are lawyers so much interested in the patients' rights and their protection? What is the reason why this category is specifically and distinctly protected by the law? This approach may seem odd since nobody would be deprived of their rights and freedoms as a human being by simply becoming a patient.

Relations between patients and entities providing healthcare services are of a special character. What draws particular attention is that in these relations, the patient's position is weaker as he/she, due to lack of knowledge and skills, is not able to assess the professional's action. This relation, in itself, is asymmetrical and becomes even more difficult for the patient in a situation when he/she is to face and cope with the organized health care institutions' structures. The anonymity of patients who are being treated solely as medical cases and who are treated by a team of professionals, has always posed a serious risk to the idea of patients' autonomy. Also, the cases known from history ${ }^{11}$ on treating people as subjects for scientific experiments or performing medical experiments on them without them being aware of it, leads to the conclusion that patients' protection is necessary so as to introduce balance in healthcare system relations.

Therefore, the basic factor influencing the development of the concept of patients' rights, is the prevention of a situation where patients would be treated as objects. This risk has progressively become more appalling consistent with the progress made in medicine and development of healthcare systems.

The fundamental aspect of patients' rights consists of the idea of protection of human life, freedom, dignity and privacy in a specific situation of one's life: when benefiting from health care services.

The introduction of the new human rights category - patients' rights, has triggered the development of a new legal field dealing with this category. New questions have arisen on the substance of particular rights (since every right creates specific obligations). There also occurred a necessity to find a compromise between legitimate patients' interests and the obligations of medical personnel since patients'

10 According to: D. Safjan, Prawa pacjenta. Raport o stanie prawnym. Helsińska Fundacja Praw Człowieka 1992.

11 See: J. Thorwald, Pacjenci, Kraków 1995. 
rights, even though legitimate, should not obstruct the practice of medical professions $^{12}$.

\section{Basic terms and definitions}

According to article 1 of the Patients' Rights Act, the scope of the act covers: patients' rights, rules on access to medical documentation, obligation of the entities providing medical services connected with the patients' rights, procedure for appointing, dismissal and competences of PRO, as well as procedure for cases of violation of patients' collective interests.

The new act also puts in order or introduces definitions of persons who are specifically entitled. It is the first time in medical legislation, that the definition of a patient appears (art. 3 paragraph 1, subparagraph 4 of the Patients' Rights Act). A patient is a person who applies to benefit from healthcare services or who makes use of those which are provided by an entity providing such services or by a person practicing a medical profession. The scope of the definition is so broad, that it may well cover both an ill and a healthy person, under the condition that the person applies to benefit from healthcare services.

The legislator introduces also the term of a close person covering: a spouse, relatives up to the second degree of affinity or consanguinity in direct line, statutory agent, a person factually in cohabitation or a person otherwise indicated by the patient. As an example of the changes under the new regulation, a close person has gained a new and important entitlement: a right to information on the patient's health in a situation where he/she is under 16 years old, is unconscious or is unable to understand the information provided ${ }^{13}$. This regulation has filled the formerly occurring gap in the law, due to which, in a situation where a given person was not entitled to obtain information on the patient's health, for example where, due to the patient being in a state of unconsciousness, the doctor could not provide the information to a close person. This situation was avoided by applying the institution of an actual custodian. It is important to note, that the actual custodian is a person who wields permanent guardianship of a patient who, regardless of age, health condition, or psychical state, requires such care (article 3, paragraph 1, subparagraph 1 of the Patients' Rights Act)

While considering the above definition, it is noticeable that not always was there a possibility of categorizing a given person as the actual custodian of the patient (as in case of a patient of full age, who previously has not been bedridden). Due to stified situations which are specified in the Mental Health Act or Act of Infectious Diseases and Infections. 
this, there was a practice of using an "over interpretation" of this term in order to allow the close persons to access information on the patient's health. There were, however, also cases when a husband was denied access on his wife's health, when she was brought unconscious to the hospital, for the reason that he could not have been categorized as the actual custodian. The current solution, which introduces a definition and entitlements of a close person, eliminated this gap in the law.

The legislator also introduced the following terms: a person practicing a medical profession and an entity providing medical benefits (article 3 paragraph 3 subparagraph 3 and 5 of the Patients' Rights Act). In the first case, these are the persons listed in article 18d, paragraph 1, subparagraph 1 of the Health Care Institutions Act (that is: persons who on the basis of separate provisions are entitled to provide medical benefits of a given scope, in a given field of medicine). In the second case, these are: the health care institutions as well as doctors', nurses', and midwives' who practice individually or as a group.

\section{Patients' individual rights}

1. The right to healthcare provided in accordance with present medical knowledge (art. 6-8 of the Patients' Rights Act)

2. The right to the clear and objective procedure based on the medical criteria procedure of establishing the order of access to medical healthcare where there is a limited possibility of providing the service (art. 6 par. 2 of the Patients` Rights Act)

3. The right to demand that the healthcare provider - a doctor or a nurse - take additional opinion of another professional and the right to demand to hold a case conference (art. 6 par. 3-6 of the Patients` Rights Act)

4. The right to obtain information about his/her health and treatment, and very detailed information about his/her rights as a patient, and also information about medical prophylactic healthcare programs provided by the institution founded by the state (art. 9-12 of the Patients' Rights Act)

5. The right to doctor-patie nt privilege (art. 13-14 of the Patients` Rights Act)

6. The right to express informed consent for treatment (art. 15-19 of the Patients` Rights Act)

7. The right to respect the patient's intimacy and dignity (art. 20 par. 1 of the Patients` Rights Act)

8. The right to die in peace and with dignity. (art. 20 par. 2 of the Patients Rights Act) 
9. The right to the presence of an intimate when healthcare services are provided (art. 21 of the Patients` Rights Act)

10. The right of access to medical documentation (art. 23-29 of the Patients' Rights Act)

11. The right to protection of medical documentation (art. 24 of the Patients' Rights Act)

12. The right to make an objection to a medical opinion or to a medical certificate (art. 31-32 of the Patients` Rights Act)

13. The right to personal contact, by telephone or by mail with the other patients that need 24h, or day-long medical treatment (art. 33 par. 1 of the Patients Rights Act)

14. The right to additional nursing care (art. 34 of the Patients` Rights Act)

15. The right to pastoral care (art. 36-38 of the Patients` Rights Act)

16. The right to put personal belongings in deposit at the medical healthcare facility (art. 39-40 of the Patients` Rights Act)

Due to the limited scope of this publication it is not possible to cover all of the laws mentioned above, so only those problems which were not expressis verbis detailed in any previous act are addressed.

One of those laws is the right to demand of a doctor, another doctor's opinion. There is a similar entitlement of the patient towards a nurse or a midwife providing medical treatment, but this one is limited to the nursing and midwifery range of services. A patient is also entitled to demand a case conference.

These rights are to give an assurance of safety to the patient who may have doubts about the treatment being provided. On the other hand, medical staff may reject such demands if they recognize them as baseless. The patient's right is strictly limited in this circumstance, because of the doctor or nurse s arbitrary decision, however, both the demand and the refusal must be noted in the medical documentation with the possibility of further legal consequences. The notation may be used by the patient-plaintiff as evidence of lack of appropriate care on the part of medical staff: there being no consultancy despite the plaintiff's well-grounded demand.

According to art. 21 of the act, the patient has the right to the presence of a relative or other person (e.g. cohabiter), when medical services are provided. Medical staff may refuse this for epidemiological reasons or to avoid unnecessary risk to the 
patients health. The request and the refusal must also be noted in the medical documentation ${ }^{14}$.

The novelty of the act, is the right to object to a medical certificate or opinion where the opinion has influence on the patient's rights or his duties arising from law. This type of objection must be submitted to the Medical Committee of the Patients' Rights Ombudsman, with the mediation of the Patients` Rights Ombudsman, within 30 days from the date the certificate or opinion was issued. The objection must be well-grounded and must include indication of the articles of law that states the rights or duties. If these conditions are not fulfilled the objection is returned to the objector.

This seems to be far too strict, the patient should not be burdened with the duty of indicating the appropriate articles of law, because the objection is submitted by mediation of the Patients' Rights Ombudsman, which is the institution established to protect the law. This office is itself capable of assessing whether the objection is justified and whether there has been a violation of law.

Follow-up procedure is conducted by a medical commission ${ }^{15}$, which examines the medical documentation and, if there is such a need, may demand additional examination of the patient. The certificate should be issued immediately, not later than 30 days from the date the objection was submitted. ${ }^{16}$ The case must be adjudicated by voting, the ordinary majority at the presence of all commission members is decisive. It is strongly criticized that there is no right to appeal. The commission, which consists of doctors, judge another doctor's certificate, which raises doubt about the impartiality of judges ${ }^{17}$.

Ratio legis of the described right to appeal against a medical certificate should be recognized as a reaction to the European Tribunal of Justice finding in the case of Alicja T. vs. Poland18. In the verdict the ETJ pronounced that lack of the right to appeal against the medical opinion which rejected the request for abortion, might be an unacceptable interference in people`s lives. (art. 8 of The Human Rights Con-

14 It should be noted that art. 5 states that generally the manager of the healthcare facility or someone authorized by the manager may introduce limitation of the patients' right in the facility if there is an epidemiological risk or because of the patients' safeness. The art. 5 also states that the right to a personal contact with visitors - relatives can be limited due to the logistic possibilities of the facility. Because the art. 5 concerns all of the patients' rights the repeating of these limitations in the art. 21 point 2 seems to be unnecessary superfluum. According to the art. 32 of the act the commission constitutes of three doctors appointed by the Patients Rights Ombudsman chosen from the list of candidates prepared by the regional consultants. At least two doctors must be the same specialty as the author of the charged certificate or opinion. The Patients ' Rights Ombudsman establishes the fee for the commissioners. The costs of the commission is covered by the state within the part dedicated to the Ombudsman.

The Thirty days term seems to be toolong it is called for the introduction of the fourteen day term, see: M. Śliwka, Ustawa o prawach pacjenta i Rzeczniku Praw Pacjenta. Komentarz, pod red. M. Nesterowicza, Warszawa 2009, p. 210.

Ibid. p. 210. The author suggests the commission that should consist of doctors and lawyers. The chairman of the commission could be the judge of the District Court in Warsaw. The complaint no $5410 / 03$. 
vention). The verdict has charged Poland for the payment of appropriate compensation "because of the unintended birth", despite the fact that no violation of law in the doctors' activity had been found.

In this case the patient, Alicja T. wanted to have an abortion because of a high level of short sightedness and the risk of total blindness. The ophthalmologist stated that there were no medical grounds on which to support this view because the child can could be delivered by cesarean section. Despite the cesarean section, which was accomplished without complication, a serious worsening of the patient's eyesight was recognized after the operation. The judicial proceedings on all instances, did not prove that ophthalmologist was guilty of medical malpractice and only such a mistake - according to Polish law - could be the bas is of the doctor's responsibility. In these circumstances, the European Tribunal of Justice, recognized that lack of the possibility for changing the ophthalmologist's certificate is a serious drawback of the system.

\section{Legal instruments used for patients' protection}

The next issue concerns the manner in which patients' rights are protected. In particular, there is the question on legal instruments provided by the act, and their preliminary assessment.

1. Article 4 of the act provides that in case of culpable infringement of a patient's rights, the court can adjudge an adequate compensation for non-pecuniary loss on the basis of article 448 of the Civil Law Code (CLD) ${ }^{19}$. Paragraph 2 of this article states that, in case of a culpable infringement of the patient's right to die in peace and dignity, the court can, on the request of the spouse, or relatives up to the second degree of affinity or consanguinity in direct line, or statutory agent, adjudge, on the basis of the article $448 \mathrm{CLD}$, an adequate sum of money for a social purpose indicated by them. On the other hand, paragraph 3 institutes limitations on the possibilities to claim compensation for non-pecuniary loss in cases of infringing some of the patients' rights. As a result, a patient cannot claim compensation for non-pecuniary loss in cases of a culpable infringement of the right to leave one's valuable belongings for safekeeping in the deposit of a stationary healthcare institution (1), infringement of the right to information on the kind and scope of medical services provided by the healthcare providers (2), infringement of the patient's right to access medical documentation on the state of his/her health.

Article 4 is an equivalent of the formerly legally binding article 19a of the Health Care Institutions Act. Therefore, it should be deemed that the views of the doctri- 
$\mathrm{ne}^{20}$ and judicature ${ }^{21}$ in article $19 \mathrm{a}$, are still valid. In particular, it should be stressed that the former article 19a of the Health Care Institutions Act and current article 4 of the Patients' Rights Act, has introduced an additional legal instrument for the protection of patients' rights, which means that it was assumed that the protection of the personal rights in case of their infringement, had not been sufficient. This so happened since not every infringement of the patients' rights could have been categorized as an infringement of personal rights.

In comparison to the former article 19a, the changes apply to the definition of the group of persons entitled to claim a sum of money for an indicated social purpose (article 4, paragraph 2) and limitations on the patients' right to receive compensation for non-pecuniary loss. (article 4, paragraph 2).

In case of a culpable infringement of the patient's right to die in peace and dignity, the legal capacity to claim a sum of money for an indicated social purpose, can be applied solely to close persons: spouse, relatives up to the second degree of affinity or consanguinity in direct line, and a statutory agent. A person factually in cohabitation has been excluded from this group. In comparison to the former legal situation, the definition of the group of entitled persons has become more detailed. Article 19a has provided for the legal capacity to the: closest relative, other statutory agent, and the actual custodian. The change which eliminated from the eligible group both the actual custodian - due to its excessively broad definition, and the other statutory agent, who - compared with the closest relative, was certainly superfluous, should be appreciated. By specifying the definition of the eligible group, the legislator could simultaneously refer to article 3, paragraph 1, subparagraph 2, which introduces the definition of a close person while it does not close the option of claiming the adequate sum of money for social purposes by the late patient's cohabiter (that is, not for their own benefit).

It should be noted that the limitations comprised in article 4, paragraph 3, do not raise doubts on the point where there is no right to claim compensation for nonpecuniary loss for the culpable infringement of the right to leave one's valuable belongings for safekeeping in the deposit of a healthcare institution. In that particular case, there is no non-material damage (non-pecuniary loss defined as pain, suffering or significant psychological discomfort). Compensation for non-pecuniary loss is a

See: M. Kolasiński, Ochrona dóbr osobistych w prawie medycznym, PiM 2002, nr 11; M. Nesterowicz, Prawa pacjenta i zadośćuczynienie pieniężne za ich naruszenie w prawie medycznym i cywilnym, PiM 2005, Nr 2; J. Jończyk, Naprawienie szkody (krzywdy) w związku z ubezpieczeniem zdrowotnym, PS 2003, nr 9; M. Safjan, Kilka refleksji wokół zadośćuczynienia pieniężnego z tytułu szkody wyrządzonej pacjentowi, PiM 2005, nr 1; A. Górski, J.P. Górski, Zadośćuczynienie za naruszenie praw pacjenta, Palestra 2005, nr 6; U. Drozdowska, Cywilnoprawna ochrona praw pacjenta, Warszawa 2007, see: M. Wałachowska, in: Ustawa o prawach pacjenta i Rzeczniku Praw Pacjenta. Komentarz, pod red. M. Nesterowicza, Warszawa 2009

21 See: Judgment of the Supreme Court dated 29.05.2007, V CSK 76/07, OSNIC 2008, no. 7-8 with a gloss of M. Wałachowska, PS 2009, no. 5; 
legal instrument aimed at awarding exclusively this kind of damage (non-pecuniary loss). Possible redress of property damage (e.g. connected with a loss of clothing) is applicable on the basis of the Ordinance of the Minister of Health of 30.07 .2010 on Stationary Healthcare Institutions' Deposits. ${ }^{22}$

Further limitations pertaining to the unavailability of the right to claim compensation for non-pecuniary loss in case of a culpable infringement of the right to access information on the kind and scope of medical services provided by the healthcare providers, does not raise doubts either.

The legislator did not introduce limitations on the instruments for legal protection of the patient's autonomy with regard to the right of access to information described in article 9, paragraph 2 of the act. The lack of the right to claim compensation for non-pecuniary loss pertains only to the right to access information on the kind and scope of services provided by a specific healthcare provider, including information on prophylactic programmes financed from public sources, which are provided by a given entity (article 12 of the act). This kind of information is displayed in a public place (in written form), in the office of the healthcare provider. Article 12, plays an organizational role; a patient should know which services are provided by a given entity. From the business activity point of view, these requirements are obvious and both the contractor and the client are interested in meeting them. Therefore, there is no need to place sanctions on these obligations by introducing the right to claim compensation for non-pecuniary loss.

However, doubts apply to the third exclusion. According to article 4, paragraph 3 , subparagraph 3 of the act, the possibility of claiming compensation for non-pecuniary loss, is excluded only in cases of culpable infringement of the right to access medical documentation with respect to the patient's state of health. The right of access to medical documentation consists of: medical documentation on the state of health (1), and health benefits provided (2). Therefore, this limitation does not pertain to the access to medical documentation in the area of healthcare services provided.

Why is the patient entitled to claim compensation for non-pecuniary loss from the infringement of the right to access medical documentation on the healthcare services provided, while, at the same time, being deprived of this right with regard to the access to data on the state of his/her health?

Enhancing legal protection of the patient's right to access the medical documentation only in a limited manner and depriving in the other does not find a justification. Moreover, this entitlement is strictly connected with the patient's right to privacy and right to consent as, by disabling the access, the patient can be deprived of

Journal of Laws No. 129, item 1068. 
adequate information. This is why it should be postulated that this kind of limitation is to be eliminated and why, in line with the principle of enhanced legal protection of medical data, the law on access to the medical documentation should be protected in a comprehensive way.

2. Article 4 of the act described above, is of a private character, while the newly introduced institution of Patients' Rights Ombudsman, is of a public character.

The PRO institution, by its name and similar tasks (from the area of human rights' protection), reminds us of the institution of ombudsman which is well anchored in European legal systems.

The legislator places the PRO in the structure of central organs of governmental administration. The PRO is appointed, dismissed and supervised by the Prime Minister, while the classical regulation for the ombudsman is connected with this institution being appointed and subordinate only to Parliament, which ensures independence from the organs of the executive branch. According to the Constitution of the Republic of Poland of 1997, ${ }^{23}$ the Civil Rights' Ombudsman is independent in its actions from other state organs and is responsible only to the lower house of the Polish Parliament. Similar regulation applies to the Children Rights Ombudsman.

The difference in treatment of the PRO against the organs of governmental administration and in comparison to the other ombudsmen - Civil Rights Ombudsman and Children Rights Ombudsman - is justified by the fact that the PRO is equipped with competences of a different kind, primarily, competences of power. In cases of violation of the so-called patients' collective interests, the PRO is entitled to impose an administrative penalty. However, in cases of actions connected with the infringement of the so-called patients' individual rights, PRO competences are regulated analogically to those of the Civil Rights Ombudsman. As it may seem, in practice, patients will use the patients' individual rights' infringement case provisions, since, as the act states, it is possible to prove infringement of the collective patients' rights only in very specific situations. In particular, the total of patients' individual rights infringements does not constitute a violation of the patients' collective rights.

According to the provisions of the act, the violation of the patients' collective rights is defined as an unlawful organized act, or act of abandonment by the entity providing healthcare services and a protest action, adjudicated with a legally binding court sentence aimed at depriving or limiting patients of their rights, in particular if these actions are intended to bring material benefits. The manner in which the practices violating patients' collective interests is defined, refers to the definition of practices infringing consumers' collective interests. According to article 24,

Journal of Laws No. 78 , item 483 with changes. 
paragraph 2 of the Act of 16.02.2007 on Competition and Consumer Protection, ${ }^{24}$ a practice violating collective consumer interests shall mean unlawful activity of an undertaking prejudicial to those interests, in particular application of the provisions of standard forms of agreement entered in the register of the stipulations of standard forms of agreement that have not been pronounced inadmissible, a breach of the duty to provide consumers with reliable, truthful and complete information, unfair or misleading advertising, and other acts of unfair competition. It should be noted that in case of a paid healthcare service (that is a commercial service) the patient occurs also in the role of consumer. In such a case he is protected both by the patients' rights law, as well as the consumers' law ${ }^{25}$.

The statutory definition of practices violating patients' collective rights is imprecise. First of all, there is concern that it may be interpreted in a too broad a manner. It should be remembered, that in reality in Poland, the violation of patients' collective rights often occurs in cases where there are insufficient financial resources. Therefore, the liability for these kinds of infringements should pertain also to the "health care services taxpayer", that is the health insurer (The National Health Fund $)^{26}$. The second case of violation of collective rights, concerns organizing a protest action or strike against the rule of law. The same causes (financial pressure) often result in protest action by medical personnel. As it may seem, these cases of violating patients' collective rights should be solved by improving the existing healthcare system - and not by penalizing healthcare providers whose financial situation is already unfavourable.

It is worth noting that the PRO is entitled to impose heavy financial penalties in cases where its decision has not been implemented by healthcare providers. According to article 68 of the act, the PRO by way of administrative decision, imposes a penalty of 500.000 zloty where actions defined in previously issued administrative decisions have not been implemented, which aims at removing the effects of violating the warrant of abandoning the violation of rights. In cases where documentation and information on actual practices required by RPO has not been provided, the penalty is 50.000 zloty.

This type of competences are not, as previously described, used by either the Civil Rights Ombudsman or the Children Rights' Ombudsman. However, if we take a closer look at the PRO competences, there are some similarities in these competences in cases of violating the patients' individual rights (articles 50-53 of the act).

Journal of Laws No. 50, item 337 with changes.

Besides the aforementioned act, another one should be indicated: the act of act of 27 July 2002 on specific terms and conditions of consumer sale and amendments to the Civil Code.

For more information go to: U. Drozdowska, Rzecznik Praw Pacjenta - nowy sposób ochrony praw pacjenta?,

Zeszyty Naukowe WSAP im. S. Staszica w Białymstoku 2009, No. 1 
The explanatory proceedings on the violation of the patients' individual rights can result in two ways. PRO explains to the applicant and the concerned patient that there was no infringement of the patient's right. This decision is also sent to the provider concerned. To this decision, a case to move for a new trial is applicable.

However, in cases where infringement was affirmed by PRO, PRO can proceed with the action directly to the institution where the infringement of the patients' right was deemed to have taken place. In such an address the PRO formulates his conclusions and opinions, also require an initiation of disciplinary proceedings or impose official sanctions on the persons guilty of the violation/infringement; the addressee then has 30 days in which to take a stand on the issue and for informing the PRO on the action taken (which means that he/she may not share the views of PRO and take no action at all).

The PRO may proceed with the action directly towards the institution superior to the one which is being accused of infringing patients' rights by applying for the implementation of the means provided by law. This kind of address is possible in a situation where the entity towards which the accusation was filed had not shared the position of the PRO or had not taken any action preventing the infringement of patients' rights. Analysis of the Patients' Rights Act, leads to the conclusion that actions taken by the PRO - referred to as addresses or explanations - are not in the form of administrative decisions. Similar addresses are issued by the Civil Rights Ombudsman, in cases where civil rights are violated. It is reiterated in the judicature, that addresses issued by the CRO to various institutions and organs are not issued in a form provided by articles 3, paragraph 2, subparagraphs $1-4$ of the Law on Proceedings before Administrative Courts, ${ }^{27}$ and as a result, according to the rules of the aforementioned law, they are non-actionable. A similar approach should be applied to the PRO. Following, the addresses and explanations of the PRO will be enforced by the institution's authority rather than by competences provided by the law itself. Taking into account the abovementioned arguments, we should wish that the RPO is able to gain as much authority in Poland as the Civil Rights Ombudsman.

27 Decision of Voivodeship/Provincional Administrative Court in Warsaw dated 24.11.2004, II SAB/Wa 343/04. See also: E. Bagińska, in: Komentarz do ustawy o prawach pacjenta i Rzeczniku Praw Pacjenta, pod red. M. Nesterowicza, op. cit., p. 271. 


\section{PATIENTS' RIGHTS PROTECTION MODEL IN THE PATIENTS' RIGHTS AND PATIENTS' RIGHTS OMBUDSMAN ACT OF 6.11.2008}

Patients' rights constitute a new field of law which undoubtedly needs an in depth reflection from a legal perspective. The author discussing present acts (after introduction of Patients' Rights and Patients' Rights Ombudsman Act) analyze the legal position of patient. It is necessary to consider whether sanctions for the infringements of the patients' rights are properly selected and adequately constructed. First of all, positive assessment should be given to the sanction from the article 4 of the act, which provides for a compensation for a non-pecuniary loss in case of an infringement of the patients' rights.

The establishment of the Patients' Rights Ombudsman (PRO) for the purposes of institutionalized protection of patients' rights should be, in principle, assessed as a positive step. The hybrid character of the institution is also noteworthy. On one hand, the PRO is a special kind of ombudsman appointed to control the observance of the rights of particular groups of people, on the other hand is the central organ of the governmental administration. It may also be assumed that just as the patients' rights form a more specialized type of the human rights, the PRO is a „subtype" of the Civil rights Ombudsman. However, it is not exactly the case, as the PRO is the central organ of the governmental administration, and can use the competence of power only in cases of violation of the patients' collective interests, while at the same time, no such competences can be used with respect to the infringement of the patients' individual rights.

Key words: patient, patient's individual rights, health care, infringement of the patients' rights, sanctions 


\section{MODEL OCHRONY PRAW PACJENTA NA GRUNCIE USTAWY Z DNIA 6 XI 2008 R. O PRAWACH PACJENTA I RZECZNIKU PRAW PACJENTA (DZ.U. Z 2009 R., NR 52, POZ. 417)}

Prawa pacjentów stanowią nową dziedzinę prawa, która bez wątpienia wymaga pogłębionej refleksji z prawnego punktu widzenia. Autorka prezentując obowiązujący stan prawny (po wejściu w życie ustawy z dnia 6 listopada 2008 r. o prawach pacjenta i Rzeczniku Praw Pacjenta) poddaje analizie sytuację prawną pacjenta. Należy zastanowić się, w tym kontekście, nad tym czy sankcje za naruszanie praw pacjentów zostały poprawnie wybrane i odpowiednio skonstruowane. Przede wszystkim należy pozytywnie ocenić sankcję $\mathrm{z}$ artykuł 4 ustawy, który przewiduje kompensację za szkodę niemajątkową w przypadku naruszenia praw pacjentów.

Ustanowienie Rzecznika Praw Pacjenta dla zinstytucjonalizowanej ochrony praw pacjentów w tej perspektywie należy w zasadzie ocenić pozytywnie. Wart jest odnotowania hybrydowy charakter tej instytucji. Z jednej strony Rzecznik Praw Pacjenta jest szczególnym rodzajem Rzecznika Praw Obywatelskich powołanym do kontrolowania przestrzegania praw określonej grupy osób, z drugiej zaś jest organem administracji państwowej.

Można poczynić założenie, że podobnie jak prawa pacjenta stanowią szczególny rodzaj praw człowieka, tak Rzecznik Praw Pacjenta stanowi ,podtyp” Rzecznika Praw Obywatelskich. Nie jest to jednak do końca prawdziwa teza, gdyż Rzecznik Praw Pacjenta - jako centralny organ administracji rządowej może wykonywać kompetencje władcze tylko w sprawach o naruszenie zbiorowych interesów pacjentów, podczas gdy nie jest władny do wykonywania takich kompetencji w odniesieniu do naruszeń indywidualnych praw pacjentów. 